\title{
Yield and morphological characteristics of Burdock (Arctium lappa L.) in response to mineral fertilizer application
}

\author{
Mbappe Tanga ${ }^{1}$, Francis Bayo Lewu ${ }^{2 *}$, Adebola Omowunmi Oyedeji ${ }^{3}$, Opeoluwa Oyehan Oyedeji ${ }^{4}$ \\ ${ }^{1}$ Department of Environment and Occupational studies, Faculty of Applied Science, Cape Peninsula University of \\ Technology, Cape Town, South Africa \\ ${ }^{2}$ Department of Agriculture, Faculty of Applied Science, Cape Peninsula University of Technology, Wellington, South Africa \\ ${ }^{3}$ Department of Chemical and Physical Sciences, Faculty of Natural Sciences, Walter Sisulu University of Science and \\ Technology, South Africa \\ ${ }^{4}$ Department of Chemistry, Faculty of Science and Agriculture, University of Fort Hare, Alice, South Africa
}

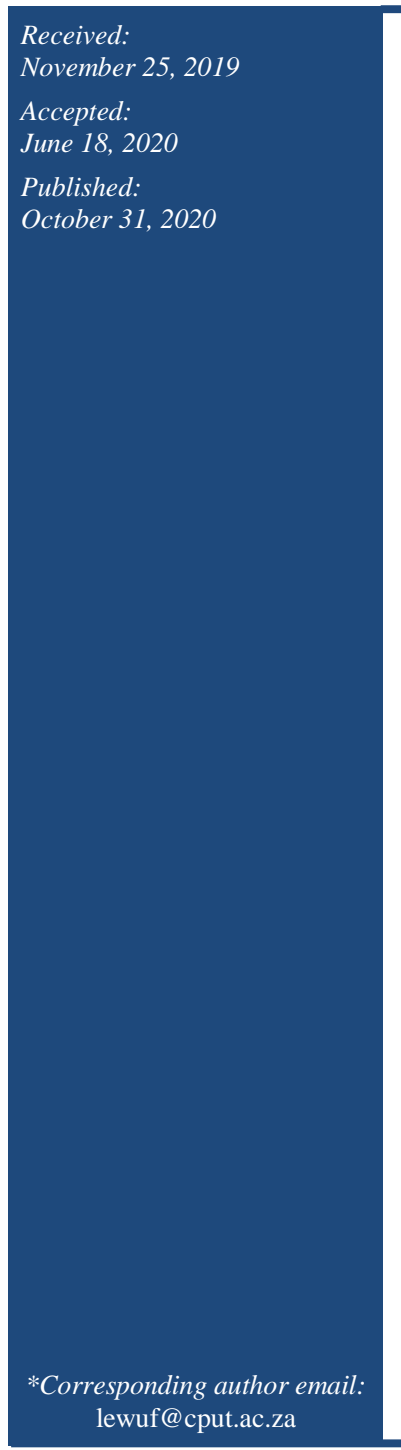

\begin{abstract}
Burdock (Arctium lappa L.) is a medicinal plant, highly rich in phytochemicals which contribute towards its antioxidant properties and treatment of chronic diseases. It is also consumed as a vegetable in some regions of the world because of its high nutritive value. Currently, the plant material is imported for its medicinal purposes by herbal practitioners and pharmaceutical industries in the different countries of the world, including South Africa. However, the cultivation of this plant is lacking in South Africa and Africa as a whole. In order to achieve consistent supply of quality products and eliminate batch-to-batch variability of plant materials, a factorial experiment was conducted on Takinogawa long cultivar with eight treatments $\left(\mathrm{T}_{1}=\mathrm{N}_{423} \mathrm{P}_{210} \mathrm{~K}_{315}\right.$, $\mathrm{T}_{2}=\mathrm{N}_{423} \mathrm{P}_{280} \mathrm{k}_{315}, \mathrm{~T}_{3}=\mathrm{N}_{635} \mathrm{P}_{210} \mathrm{~K}_{315}, \mathrm{~T}_{4}=\mathrm{N}_{635} \mathrm{P}_{280} \mathrm{~K}_{315}, \mathrm{~T}_{5}=\mathrm{N}_{846} \mathrm{P}_{210} \mathrm{~K}_{315}, \mathrm{~T}_{6}=\mathrm{N}_{846} \mathrm{P}_{280} \mathrm{~K}_{315}$, $\mathrm{T}_{7}=\mathrm{N}_{1058} \mathrm{P}_{210} \mathrm{~K}_{315}$ and $\mathrm{T}_{8}=\mathrm{N}_{1058} \mathrm{P}_{280} \mathrm{~K}_{315} \mathrm{Kg} / \mathrm{ha}$ ) and five collection time of data laid out in a completely randomized design replicated five times under $40 \%$ shade net. Fertilizer treatments were split into two equal doses at seedling transplant and four weeks after transplant. Data on morphological characteristics and yield were collected and analyzed using SAS software. There was a significant $(\mathrm{P}<0.05)$ difference across fertilizer treatments on morphological characteristics as well as the interactions between treatments and time of data collection. Significant differences $(\mathrm{P}<0.05)$ were also recorded on the yield parameters. Two treatments $\left(\mathrm{N}_{635} \mathrm{P}_{210} \quad \mathrm{~K}_{315}\right.$ and $\mathrm{N}_{635} \mathrm{P}_{280} \mathrm{~K}_{315} \mathrm{Kg} / \mathrm{ha}$ ) significantly outperformed the other treatments. However, more research needs to be done on the enhancement of secondary metabolites of interest for the sustainable supply of quality plant materials for herbal practitioners and pharmaceutical industries.
\end{abstract}

Keywords: Arctium lappa L., Medicinal plant, Phytochemicals, Morphological characteristics, Fertilizer treatments

\section{How to cite this:}

Tanga M, Lewu FB, Oyedeji AO and Oyedeji OO, 2020. Yield and morphological characteristics of Burdock (Arctium lappa L.) in response to mineral fertilizer application. Asian J. Agric. Biol. 8(4): 511-518. DOI: https://doi.org/10.35495/ajab.2019.11.524

This is an Open Access article distributed under the terms of the Creative Commons Attribution 3.0 License. (https://creativecommons.org/licenses/by/3.0), which permits unrestricted use, distribution, and reproduction in any medium, provided the original work is properly cited. 


\section{Introduction}

The increase in demand for plant-based products for food, medicine, shelter, agrochemicals, and clothing by the increasing human population is causing pressure on wild plant populations. This scenario keeps increasing especially for plant species that have been identified for the possession of valuable phytochemicals of therapeutic values. Presently, the increasing demand for plant-derived natural products has created a large business opportunity for medicinal plant materials especially in developing countries where approximately $80 \%$ of both rural and urban populations prefer the use of traditional medicine because of its affordability and cultural acceptability (Maroyi, 2013). This has placed significant pressure on our plant biodiversity with very little or no mitigating measures like the cultivation of medicinal plants of interest. Cultivation and optimum management practice of these species especially defining the best fertilizer application rate for optimum growth and yield of secondary metabolites of interest is imperative. Arctium lappa L. is a biennial plant of the family Asteraceae and has been documented in the Traditional Chinese medicine (TCM) to contain phytochemicals of phenolic compounds such as chlorogenic, caffeic, isochlorogenic, polyacetylenes, triterpenoids, lignans arctiin and arctigenin (Tousch et al., 2014; Chan et al., 2011). The species has antioxidant, anti-microbial, antidiabetic, antiallergic, anti-inflammatory, sedative, and other health-protecting properties (El-Darier and Salama, 2016). The root is a good source of inulin, a non-starchy polysaccharide that is prebiotic and helps to reduce body weight, sugar and cholesterol level in the blood. It is also known for lowering intestinal $\mathrm{pH}$, preventing the establishment and growth of pathogenic bacteria (Wang and $\mathrm{Wu}, 2013$ ).

Apart from its medicinal potentials, Burdock is a nutritious crop that is of considerable importance in Europe, Australia and America where it is highly consumed as a vegetable in the form of stew and salad (Chan et al., 2011). Nutritionally the root and leaf constitutes a significant proportion of iron, manganese, magnesium, selenium, zinc, calcium, phosphorus, folic acid, riboflavin, pyridoxine, niacin and with some appreciable amount of potassium which is an important component of cell body fluid regulating heart beat and blood pressure (Chang et al., 2009). It is also rich in some valuable amounts of vitamin $\mathrm{C}$ and $\mathrm{E}$ which are natural antioxidants for the oxidation of easily oxidizable materials ( $\mathrm{Xu}$ et al., 2017). Morphologically burdock is characterized by heart-shaped leaves that vary in length and width from top to bottom, covering the stem. It is well adapted to full or partial sun growth and grows well in undisturbed areas. The root is fleshy with a slightly thick brown back and grows deep into a well-drained sandy soil (Wu et al., 2016). The availability and supply of these plant materials are mostly limited to the wild, with marginal cases of subsistence cultivation practices restricted mostly to countries and/or regions of its origin. Though of high medicinal and nutritional benefits with high market demand by pharmaceutical companies and herbal practitioners across the world, access to the herb is still restricted to regions of its origin, and countries like South Africa still depends solely on imported plant materials with potential batch-to-batch variability and irregular volume supply (Tanga et al., 2018). The application of modern cultivation techniques to this species will ensure a consistent supply of high-quality materials to both pharmaceutical industries and herbal practitioners. In addition, this approach could present appreciable mitigating measures against population decimation in its natural habitat. To properly adapt and domesticate new species in another environment or climatic condition, evaluation of the morphology and physiological expression of such species is a critical aspect of a preliminary study that must be conducted. This current study evaluates the morphology and yield of Arctium lappa L. in response to different application rates of $\mathrm{N}$ : $\mathrm{P}$ : $\mathrm{K}$ fertilizer planted in a pot experiment.

\section{Material and Methods}

\section{Study area}

The experiment was conducted from August 2018 to March 2019 at the Research and Teaching Farm, the Agric-Hub, Department of Agriculture, Wellington Campus, Cape Peninsula University of Technology (CPUT), South Africa. The area falls within the Northern part of Wellington at coordinate (S33 ${ }^{\circ} 37^{\prime}$ E19 $\left.{ }^{\circ} 37^{\prime}\right)$. Wellington has a Mediterranean climate and receives about $585 \mathrm{~mm}$ of winter rainfall per year. Rainfall is usually from the months of February to November, with the lowest rainfall in February (10 $\mathrm{mm}$ ) and the highest in June (105 mm). 
Table-1. Chemical properties of potted soil

\begin{tabular}{|l|c|}
\hline Soil type & Sandy \\
\hline $\mathrm{pH} \mathrm{KCl}$ & 7.1 \\
\hline Resist Ohm & 70 \\
\hline Stone V\% & 1 \\
\hline $\mathrm{P} \mathrm{mg} / \mathrm{Kg} \mathrm{Bray} \mathrm{II}$ & 418 \\
\hline $\mathrm{K} \mathrm{mg} / \mathrm{Kg}$ & 3425 \\
\hline $\mathrm{Cu} \mathrm{mg} / \mathrm{Kg}$ & 2 \\
\hline $\mathrm{Zn} \mathrm{mg/kg}$ & 33.4 \\
\hline $\mathrm{Mn} \mathrm{mg} / \mathrm{Kg}$ & 30.3 \\
\hline $\mathrm{B} \mathrm{mg} / \mathrm{kg}$ & 2.74 \\
\hline $\mathrm{Fe} \mathrm{mg} / \mathrm{kg}$ & 65 \\
\hline $\mathrm{C} \%$ & 3.6 \\
\hline $\mathrm{Total} \mathrm{N}(\mathrm{N} \%)$ & 0.35 \\
\hline $\mathrm{Na}$ & 5.49 \\
\hline $\mathrm{K}$ & 8.76 \\
\hline $\mathrm{Ca}$ & 19.73 \\
\hline $\mathrm{Mg}$ & 4.47 \\
\hline
\end{tabular}

The average daily temperatures for wellington is from $16.5^{\circ} \mathrm{C}$ in July to $28.8^{\circ} \mathrm{C}$ in February.

\section{Soil collection}

Potting soil was obtained from standard farm and analyzed in Bemlab, a commercial laboratory in the Western Cape Province, South Africa. The results of soil test (Table 1) showed that the soil is sandy, low in total nitrogen $(0.353 \%)$ and phosphorous (418 $\mathrm{mg} / \mathrm{Kg}$ ), with a moderate amount of potassium (3425 $\mathrm{mg} / \mathrm{kg}$ ) and a near to neutral $\mathrm{pH}(7.1)$.

\section{Experimental layout and treatment application}

The study was a factorial experiment of eight treatments $\quad\left(\mathrm{T}_{1}=\mathrm{N}_{423} \mathrm{P}_{210} \mathrm{~K}_{315}, \quad \mathrm{~T}_{2}=\mathrm{N}_{423} \mathrm{P}_{280} \mathrm{k}_{315}\right.$, $\mathrm{T}_{3}=\mathrm{N}_{635} \mathrm{P}_{210} \mathrm{~K}_{315}, \quad \mathrm{~T}_{4}=\mathrm{N}_{635} \mathrm{P}_{280} \mathrm{~K}_{315}, \quad \mathrm{~T}_{5}=\mathrm{N}_{846} \mathrm{P}_{210} \mathrm{~K}_{315}$, $\mathrm{T}_{6}=\mathrm{N}_{846} \mathrm{P}_{280} \mathrm{~K}_{315}, \quad \mathrm{~T}_{7}=\mathrm{N}_{1058} \mathrm{P}_{210} \mathrm{~K}_{315} \quad$ and $\left.\mathrm{T}_{8}=\mathrm{N}_{1058} \mathrm{P}_{280} \mathrm{~K}_{315} \mathrm{Kg} / \mathrm{ha}\right)$ and five collection time $\left(\mathrm{T}_{1}\right.$, $\mathrm{T}_{2}, \mathrm{~T}_{3}, \mathrm{~T}_{4}$ and $\mathrm{T}_{5}$ ) of data. The treatments consisted of 4 levels of nitrogen $\left(\mathrm{N}_{423}, \mathrm{~N}_{635}, \mathrm{~N}_{846}\right.$ and $\mathrm{N}_{1058} \mathrm{Kg} / \mathrm{ha}$ of Urea $46 \%)$, with 2 levels of phosphorous $\left(\mathrm{P}_{210}\right.$ and $\mathrm{P}_{280} \mathrm{Kg} / \mathrm{ha}$ Triple superphosphate $20 \%$ ) laid out in a completely randomized design replicated five times. A uniform base application of potassium $\left(\mathrm{K}_{315} \mathrm{Kg} / \mathrm{ha}\right.$ of Potassium Chloride 50\%) was applied to all the treatments. The experiment was set in pots under a $40 \%$ shade net. Burdock seeds (Takinogawa long cultivar) were obtained from "The Seed Collection Pty Ltd", a company in Australia (Ferntree Gully, Victoria
3156 Australia with permit NO. P0084124). The seeds were nursed in a greenhouse using plastic tray filled with potting soil. Regular watering was done in the morning and evening to keep the soil moist. At three weeks, $100 \%$ germination of sown seeds was obtained. At six weeks the seedlings were taken outside for acclimatization over a period of two weeks before transplanting to larger pots of $10 \mathrm{~kg}$ potting soil. Application of fertilizer treatments was split into two equal doses; one at seedling transplant and four weeks after seedlings transplant. At two weeks after the transplant, fungi treatment was applied using systemic fungicide (Funginex- Reg No, L2469/N-AR0131 Wet Nr.36 van 1947 W130281 of the active ingredient Triforine) against black spot, powdery mildew, and rust. The treatment application dose was $15 \mathrm{ml} / \mathrm{L}$ of water. Three treatments were applied on the foliage randomly at weekly intervals using a Trade Air HighPressure Spraying Gun model TOOS1785.

\section{Data collection}

Data were collected on the morphological characteristics and yield parameters of burdock. Data on plant height, number of leaves per plant, leaf length, leaf width, and chlorophyll content were measured and recorded at two weeks' interval until maturity at 120 days and above when the first leaves started showing signs of aging and collapsing, indicating senescence phase. Plant height, leaf length and broadest width of plant leaves were measured using a meter rule. Number of leaves per plant was counted and the chlorophyll content of leaves was measured using a chlorophyll meter CCM- 200 plus. Data on morphological parameters was collected five times. At maturity, plants were harvested and washed using tap water. Data on yield was collected on plant biomass, root fresh weight, leaf fresh weight using a Lasec, Radwang wagi`s electronic weighing balance, Model: WLC 1/A2/C/2, made in Poland (EU). Root length and root diameter were measured using a thread and subsequently calibrated on a meter rule.

\section{Statistical analysis}

The data collected on growth and yield parameters were captured in Excel and statistical analysis was done using two-way ANOVA at $95 \%$ confidence limit using the SAS software. Means separation was done using the Fisher's Least Significant Difference (LSD) and Duncan's Multiple Range Test (DMRT). 


\section{Results}

\section{Influence of fertilizer treatments on morphological characteristics of burdock}

The different fertilizer treatments had a significant $(\mathrm{P}<0.05)$ influence on the different morphological parameters of burdock (Arctium lappa L) investigated (Table $2 \mathrm{a}) . \mathrm{T}_{3}$ recorded the highest number of leaves per plant with a $17.4 \%$ yield increase, followed by $\mathrm{T}_{4}$ with $13.8 \%$ more leaves compared to the control $\left(\mathrm{T}_{1}\right)$. Interestingly, there was a $10.8 \%$ drop in the number of leaves in $\mathrm{T}_{7}$ which had a high nitrogen application compared to the control $\left(\mathrm{T}_{1}\right)$.

Table-2a. Morphological characteristics of burdock with different fertilizer treatments. Values are means at $(\mathrm{P}$ - value $\mathbf{0 . 0 5})$.

\begin{tabular}{|c|c|c|c|c|c|}
\hline Treatments & $\begin{array}{c}\text { Number } \\
\text { of leaves }\end{array}$ & $\begin{array}{c}\text { Plant } \\
\text { height }(\mathbf{c m})\end{array}$ & $\begin{array}{c}\text { Leaf } \\
\text { length }(\mathbf{c m})\end{array}$ & $\begin{array}{c}\text { Leaf } \\
\text { width } \\
(\mathbf{c m})\end{array}$ & $\begin{array}{c}\text { Leaf } \\
\text { Chlorophyll }\end{array}$ \\
\hline $\mathrm{T}_{1}\left(\mathrm{~N}_{1} \mathrm{P}_{1} \mathrm{k}_{1}\right)$ & $6.68^{\mathrm{c}}$ & $18.36^{\mathrm{e}}$ & $18.88^{\mathrm{c}}$ & $18.64^{\mathrm{c}}$ & $15.46^{\mathrm{d}}$ \\
\hline $\mathrm{T}_{2}\left(\mathrm{~N}_{1} \mathrm{P}_{2} \mathrm{k}_{1}\right)$ & $6.48^{\mathrm{c}}$ & $20.88^{\mathrm{d}}$ & $18.56^{\mathrm{c}}$ & $18.20^{\mathrm{c}}$ & $16.73^{\mathrm{cd}}$ \\
\hline $\mathrm{T}_{3}\left(\mathrm{~N}_{2} \mathrm{P}_{1} \mathrm{k}_{1}\right)$ & $7.84^{\mathrm{a}}$ & $28.00^{\mathrm{a}}$ & $23.72^{\mathrm{a}}$ & $24.44^{\mathrm{a}}$ & $19.45^{\mathrm{b}}$ \\
\hline $\mathrm{T}_{4}\left(\mathrm{~N}_{2} \mathrm{P}_{2} \mathrm{k}_{1}\right)$ & $7.60^{\mathrm{a}}$ & $26.04^{\mathrm{b}}$ & $23.48^{\mathrm{a}}$ & $24.48^{\mathrm{a}}$ & $22.14^{\mathrm{a}}$ \\
\hline $\mathrm{T}_{5}\left(\mathrm{~N}_{3} \mathrm{P}_{1} \mathrm{k}_{1}\right)$ & $7.16^{\mathrm{b}}$ & $24.88^{\mathrm{b}}$ & $22.44^{\mathrm{a}}$ & $23.12^{\mathrm{ab}}$ & $19.99^{\mathrm{b}}$ \\
\hline $\mathrm{T}_{6}\left(\mathrm{~N}_{3} \mathrm{P}_{2} \mathrm{k}_{1}\right)$ & $6.84^{\mathrm{bc}}$ & $23.04^{\mathrm{c}}$ & $20.84^{\mathrm{b}}$ & $22.68^{\mathrm{b}}$ & $18.64^{\mathrm{cb}}$ \\
\hline $\mathrm{T}_{7}\left(\mathrm{~N}_{4} \mathrm{P}_{1} \mathrm{k}_{1}\right)$ & $5.96^{\mathrm{d}}$ & $18,48^{\mathrm{e}}$ & $14.48^{\mathrm{e}}$ & $15.20^{\mathrm{d}}$ & $15.19^{\mathrm{d}}$ \\
\hline $\mathrm{T}_{8}\left(\mathrm{~N}_{4} \mathrm{P}_{2} \mathrm{k}_{1}\right)$ & $6.80^{\mathrm{bc}}$ & $19.12^{\mathrm{e}}$ & $16.24^{\mathrm{d}}$ & $16.12^{\mathrm{d}}$ & $18.42^{\mathrm{cb}}$ \\
\hline $\mathrm{LSD}^{\mathrm{cb}}$ & 0.41 & 1.24 & 1.34 & 1.56 & 2.10 \\
\hline
\end{tabular}

Means in the same column with the same superscript are not significantly different $(\mathrm{P} \geq 0.05) . \quad \mathrm{LSD}=$ Least significant difference, $\mathrm{T}_{1=} \mathrm{N}_{423} \mathrm{P}_{210} \mathrm{~K}_{315}, \mathrm{~T}_{2}=\mathrm{N}_{423} \mathrm{P}_{280} \mathrm{~K}_{315}$, $\mathrm{T}_{3=} \mathrm{N}_{635} \mathrm{P}_{210} \quad \mathrm{~K}_{315}, \quad \mathrm{~T}_{4=} \mathrm{N}_{635} \mathrm{P}_{280} \quad \mathrm{~K}_{315}, \mathrm{~T}_{5=} \mathrm{N}_{846} \mathrm{P}_{210} \quad \mathrm{~K}_{315}$, $\mathrm{T}_{6=} \mathrm{N}_{846} \mathrm{P}_{280} \mathrm{~K}_{315}, \mathrm{~T}_{7=} \mathrm{N}_{1058} \mathrm{P}_{210} \mathrm{~K}_{315}$ and $\mathrm{T}_{8=} \mathrm{N}_{1058} \mathrm{P}_{280} \mathrm{~K}_{315}$ $\mathrm{Kg} / \mathrm{ha}$.

Plant height and leaf length demonstrated a similar response to fertilizer treatments as the number of leaves per plant. There was a $52.5 \%\left(\mathrm{~T}_{3}\right)$ and $41.8 \%\left(\mathrm{~T}_{4}\right)$ increase in plant height compared to the control $\left(\mathrm{T}_{1}\right)$. Similarly, $\mathrm{T}_{3}$ and $\mathrm{T}_{4}$ recorded the highest leaf length of $25.6 \%$ and $24.4 \%$ respectively. For the same parameter (leaf length), $\mathrm{T}_{7}$ recorded a $23.3 \%$ yield reduction compared to the control $\left(T_{1}\right)$. The highest yield increase was recorded for leaf width at $\mathrm{T}_{4}$, representing a $31.1 \%$ increase, while the least effect was recorded by $\mathrm{T}_{7}$ with $18.5 \%$ reduction compared to the control. Similarly, $\mathrm{T}_{4}$ recorded the highest leaf chlorophyll content with a $43.2 \%$ increase and $\mathrm{T}_{7}$ recorded a $1.7 \%$ reduction compared to the control $\left(\mathrm{T}_{1}\right)$. Number of leaves per plant, plant height, and chlorophyll content had a positive correlation to fertilizer treatments, while leaf length and leaf width had negative correlation to fertilizer treatments, with acceptable tolerance values over 0.1 and VIF values less than 10 (Table 2b).

\section{Influence of time of data collection on morphological characteristics of burdock}

The different morphological parameters of burdock investigated in this study progressively $(\mathrm{P}<0.05)$ increased with age exponentially (Fig 1). However, some parameters showed slight resilience with advancing age. Number of leaves and plant height increased significantly $(\mathrm{P}<0.05)$ with age whereas leaf length and leaf width had no significant $(\mathrm{P}>0.05)$ increase after the fourth time of data collection (16 weeks). Also, leaf chlorophyll content did not show a significant $(\mathrm{P}>0.05)$ increase between the third and fourth time of data collection. Overall, between the fourth and fifth time of data collection, there was a significant increase of $22 \%$ in the number of leaves per plant, $5.1 \%$ in plant height and $6.5 \%$ in leaf chlorophyll content. Though not statistically significant, leaf length and leaf width recorded $4.4 \%$ and $2.6 \%$ respectively between the fourth and the fifth time of data collection. Whereas, between the third and fourth time of data collection on leaf chlorophyll content, a non-significant $5.6 \%$ increase was recorded.

Table-2b. Correlations on Morphological characteristic at (P-value 0.05).

\begin{tabular}{|c|c|c|c|c|c|c|c|c|c|}
\hline \multicolumn{10}{|c|}{ Coefficients $^{\mathrm{a}}$} \\
\hline \multirow{2}{*}{ Model } & \multicolumn{2}{|c|}{$\begin{array}{c}\text { Unstandardized } \\
\text { Coefficients } \\
\end{array}$} & \multirow{2}{*}{$\begin{array}{c}\begin{array}{c}\text { Standardized } \\
\text { Coefficients }\end{array} \\
\text { Beta } \\
\end{array}$} & \multirow[t]{2}{*}{$\mathbf{t}$} & \multirow{2}{*}{ Sig. } & \multicolumn{2}{|c|}{$\begin{array}{l}95.0 \% \text { Confidence Interval for } \\
\text { B }\end{array}$} & \multicolumn{2}{|c|}{ Collinearity Statistics } \\
\hline & B & Std. Error & & & & Lower Bound & Upper Bound & Tolerance & VIF \\
\hline (Constant) & 5.567 & .720 & & 7.728 & .000 & 4.146 & 6.988 & & \\
\hline Plant height & .092 & .046 & .274 & 1.986 & .048 & .001 & .184 & .235 & 4.258 \\
\hline Number of leaves & .053 & .163 & .039 & .326 & .745 & -.269 & .376 & .315 & 3.176 \\
\hline Leaf width & -.007 & .059 & -.016 & -.112 & .911 & -.122 & .109 & .225 & 4.435 \\
\hline Leaf length & -.263 & .070 & -.618 & -3.736 & .000 & -.402 & -.124 & .163 & 6.138 \\
\hline Chlorophyll & .101 & .038 & .223 & 2.641 & .009 & .025 & .176 & .627 & 1.594 \\
\hline \multicolumn{10}{|c|}{ a. Dependent Variable: TREATMENT } \\
\hline
\end{tabular}




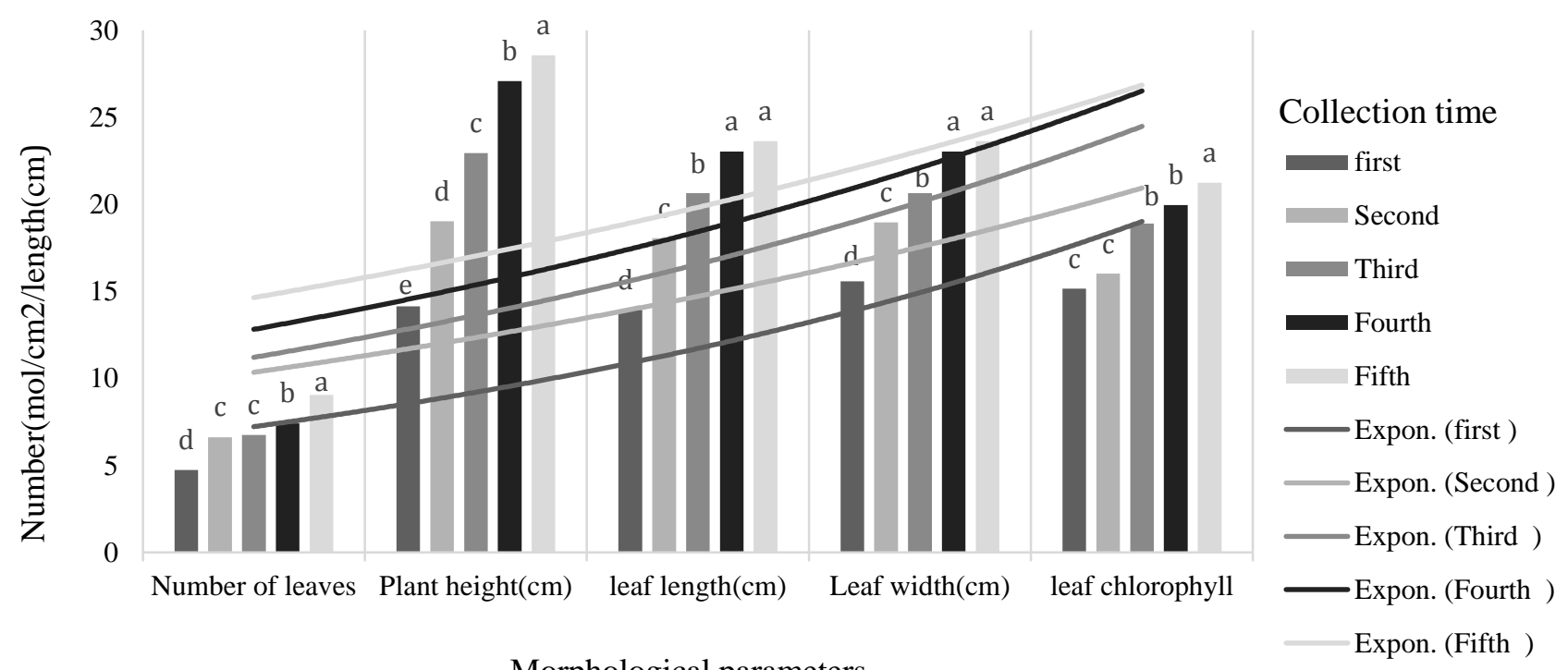

Figure-1. Graph showing the influence of time on data collection on morphological characteristics of burdock. Values are means at $(\mathbf{P}=\mathbf{0 . 0 5})$. Bars with the same letter on each parameter are not statistically different $(\mathrm{P} \geq \mathbf{0 . 0 5})$. Least significant difference $(\mathrm{LSD})$ for number of leaves $=0.32$, plant height $=0.98$, leaf length $=1.06$, leaf width $=1.24$ and leaf chlorophyll=1.67).

Table-3. Influence of different fertilizer treatments on yield related parameters of burdock at (P- values 0.05$)$.

\begin{tabular}{|c|c|c|c|c|c|c|c|c|}
\hline Treatments & $\begin{array}{c}\text { Total fresh } \\
\text { weight } \\
\text { (tons/ha) }\end{array}$ & $\begin{array}{c}\text { Fresh root } \\
\text { weight } \\
\text { (tons/ha) }\end{array}$ & $\begin{array}{c}\text { Fresh leaf } \\
\text { weight } \\
\text { (tons/ha) }\end{array}$ & $\begin{array}{c}\text { Root } \\
\text { length } \\
\text { (cm) }\end{array}$ & $\begin{array}{c}\text { Root } \\
\text { diameter } \\
(\mathbf{c m})\end{array}$ & $\begin{array}{c}\text { Leaf dry } \\
\text { weight } \\
\text { (tons/ha) }\end{array}$ & $\begin{array}{c}\text { Root dry } \\
\text { weight } \\
\text { (tons/ha) }\end{array}$ & $\begin{array}{c}\text { Total dry } \\
\text { weight } \\
\text { (tons/ha) }\end{array}$ \\
\hline $\mathrm{T}_{1}\left(\mathrm{~N}_{1} \mathrm{P}_{1} \mathrm{k}_{1}\right)$ & $80.12^{\mathrm{bc}}$ & $62.17^{\mathrm{b}}$ & $17.24^{\mathrm{bc}}$ & $19.70^{\mathrm{abc}}$ & $6.48^{\mathrm{c}}$ & $7.24^{\mathrm{c}}$ & $31.84^{\mathrm{b}}$ & $39.08^{\mathrm{bc}}$ \\
\hline $\mathrm{T}_{2}\left(\mathrm{~N}_{1} \mathrm{P}_{2} \mathrm{k}_{1}\right)$ & $53.05^{\mathrm{d}}$ & $42.47^{\mathrm{c}}$ & $11.36^{\mathrm{c}}$ & $18.60^{\mathrm{bc}}$ & $6.14^{\mathrm{c}}$ & $6.68^{\mathrm{c}}$ & $23.56^{\mathrm{c}}$ & $30.24^{\mathrm{d}}$ \\
\hline $\mathrm{T}_{3}\left(\mathrm{~N}_{2} \mathrm{P}_{1} \mathrm{k}_{1}\right)$ & $112.46^{\mathrm{a}}$ & $87.39^{\mathrm{a}}$ & $24.16^{\mathrm{ab}}$ & $21.60^{\mathrm{ab}}$ & $7.88^{\mathrm{a}}$ & $15.48^{\mathrm{ab}}$ & $63.48^{\mathrm{a}}$ & $78.96^{\mathrm{a}}$ \\
\hline $\mathrm{T}_{4}\left(\mathrm{~N}_{2} \mathrm{P}_{2} \mathrm{k}_{1}\right)$ & $95.40^{\mathrm{ab}}$ & $67.43^{\mathrm{b}}$ & $21.42^{\mathrm{ab}}$ & $21.20^{\mathrm{abc}}$ & $7.66^{\mathrm{ab}}$ & $11.84^{\mathrm{ab}}$ & $43.44^{\mathrm{b}}$ & $62.88^{\mathrm{ab}}$ \\
\hline $\mathrm{T}_{5}\left(\mathrm{~N}_{3} \mathrm{P}_{1} \mathrm{k}_{1}\right)$ & $91.12^{\mathrm{ab}}$ & $64.01^{\mathrm{b}}$ & $28.03^{\mathrm{a}}$ & $20.80^{\mathrm{abc}}$ & $7.10^{\mathrm{abc}}$ & $18.84^{\mathrm{a}}$ & $31.80^{\mathrm{b}}$ & $42.92^{\mathrm{ab}}$ \\
\hline $\mathrm{T}_{6}\left(\mathrm{~N}_{3} \mathrm{P}_{2} \mathrm{k}_{1}\right)$ & $83.34^{\mathrm{bc}}$ & $57.32^{\mathrm{bc}}$ & $25.73^{\mathrm{a}}$ & $22.10^{\mathrm{a}}$ & $6.58^{\mathrm{bc}}$ & $11.16^{\mathrm{b}}$ & $30.20^{\mathrm{bc}}$ & $41.40^{\mathrm{bc}}$ \\
\hline $\mathrm{T}_{7}\left(\mathrm{~N}_{4} \mathrm{P}_{1} \mathrm{k}_{1}\right)$ & $61.53^{\mathrm{cd}}$ & $39.57^{\mathrm{c}}$ & $20.62^{\mathrm{ab}}$ & $20.60^{\mathrm{abc}}$ & $6.10^{\mathrm{c}}$ & $8.16^{\mathrm{bc}}$ & $19.28^{\mathrm{c}}$ & $27.44^{\mathrm{cd}}$ \\
\hline $\mathrm{T}_{8}\left(\mathrm{~N}_{4} \mathrm{P}_{2} \mathrm{k}_{1}\right)$ & $64.81^{\mathrm{cd}}$ & $43.41^{\mathrm{c}}$ & $20.95^{\mathrm{ab}}$ & $18.20^{\mathrm{c}}$ & $6.7^{\mathrm{bc}}$ & $11.12^{\mathrm{b}}$ & $22.96^{\mathrm{c}}$ & $34.08^{\mathrm{cd}}$ \\
\hline $\mathrm{LSD}$ & 29.12 & 19.96 & 10.80 & 3.244 & 1.102 & 3.36 & 20.04 & 37.56 \\
\hline
\end{tabular}

Means in the same column with the same superscript are not significantly different $(\mathrm{P} \geq 0.05)$. LSD $=$ Least significant difference, $\mathrm{T}_{1=} \mathrm{N}_{423} \mathrm{P}_{210} \mathrm{~K}_{315}, \mathrm{~T}_{2}=\mathrm{N}_{423} \mathrm{P}_{280} \mathrm{~K}_{315}, \mathrm{~T}_{3=} \mathrm{N}_{635} \mathrm{P}_{210} \mathrm{~K}_{315}, \mathrm{~T}_{4=} \mathrm{N}_{635} \mathrm{P}_{280} \mathrm{~K}_{315}, \mathrm{~T}_{5=} \mathrm{N}_{846} \mathrm{P}_{210} \mathrm{~K}_{315}$, $\mathrm{T}_{6=} \mathrm{N}_{846} \mathrm{P}_{280} \mathrm{~K}_{315}, \mathrm{~T}_{7=} \mathrm{N}_{1058} \mathrm{P}_{210} \mathrm{~K}_{315}$ and $\mathrm{T}_{8=} \mathrm{N}_{1058} \mathrm{P}_{280} \mathrm{~K}_{315} \mathrm{Kg} / \mathrm{ha}$.

Influence of fertilizer treatments on yield of burdock

Fertilizer treatments had a significant $(\mathrm{P}<0.05)$ influence on all the yield-related parameters recorded in burdock (Arctium lappa L). The overall fresh yield (fresh leaf weight, fresh root weight, and total fresh weight) was significantly influenced by fertilizer treatment levels. Considering total fresh weight, $\mathrm{T}_{3}$ recorded the highest (112.46tons/ha) with a $40.4 \%$ increase, while $\mathrm{T}_{2}$ recorded the lowest (53.05tons/ha) with a $33.7 \%$ decrease compared to the control $\left(\mathrm{T}_{1}\right)$.
Fresh root weight demonstrated the same response as the case of total fresh weight. However, $\mathrm{T}_{3}$ had the highest fresh root weight (87.39tons/ha) with a $40.6 \%$ increase while, $\mathrm{T}_{2}$ recorded the lowest fresh root weight (42.47tons/ha) with a $46.4 \%$ reduction compared to the control $\left(\mathrm{T}_{1}\right)$. In the case of fresh leaf weight, $\mathrm{T}_{5}$ recorded the highest (28.03tons/ha) with a $62.6 \%$ increase while $\mathrm{T}_{2}$ had the lowest fresh leaf weight (11.36 tonnes/ha) with a $34.1 \%$ decrease compared to the control $\left(\mathrm{T}_{1}\right)$. This indicates that $\mathrm{T}_{5}$ can be the potential treatment requirement for vegetable 
cultivation of burdock leaf while $\mathrm{T}_{3}$ is likely to be a potential treatment requirement for burdock root cultivation and that for total yield. Considering root length, $\mathrm{T}_{6}$ had the highest response on root length $(22.1 \mathrm{~cm})$ with a $12.2 \%$ increase and $\mathrm{T}_{3}(21.6 \mathrm{~cm})$ with a $9.6 \%$ increase while $\mathrm{T}_{8}$ recorded the lowest response in length $(18.2 \mathrm{~cm})$ with a $7.6 \%$ reduction compared to the control $\left(\mathrm{T}_{1}\right)$. Furthermore, in root collar diameter, $\mathrm{T}_{3}$ had the highest influence $(7.88 \mathrm{~cm})$ with a $21.6 \%$ increase while $\mathrm{T}_{7}$ had the lowest effect $(6.10 \mathrm{~cm})$ with a $5.9 \%$ reduction compared to the control (Table 3 ). Overall dry weight (leaf dry weight, root dry weight, and total dry weight) was significantly $(\mathrm{P}<0.05)$ influenced by fertilizer treatment levels. $\mathrm{T}_{5}$ produced the highest leaf dry weight (18.84tons/ha) representing a $160.2 \%$ yield increase compared with control $\left(T_{1}\right)$. While $\mathrm{T}_{3}$ produced the highest dry root yield (63.48tons/ha) recording a $99.4 \%$ yield increase compared to the control $\left(\mathrm{T}_{1}\right)$, profoundly, a total dry yield increase of $102.1 \%$ (78.96tons/ha) was recorded at $\mathrm{T}_{3}$. However, $\mathrm{T}_{7}$ had the lowest dry root weight (19.28tons/ha) with a $39.4 \%$ decrease and total dry weight (27.44tons/ha) with a $29.8 \%$ reduction compared to the control $\left(\mathrm{T}_{1}\right)$.

\section{Discussion}

The results of this experiment showed that fertilizer treatment combinations had significant differences in all the morphological parameters of burdock (Arctium lappa L) investigated. This may be attributed to the variation in the different rates of fertilizer application used in the study (Ichami et al., 2019; Hammed et al., 2019). These results are in line with Qasim (2018), who reported significant differences in growth and yield parameters of burdock as influenced by different levels of nitrogen fertilization and harvesting time, but with the highest effect at $100 \mathrm{~kg} / \mathrm{ha}$ of nitrogen fertilizer application in burdock plant, while in this study, the application of $635 \mathrm{~kg} / \mathrm{ha}$ had the greatest influence. This may be attributed to the differences in soil type, nutrients availability, environment, type of experiment, cultural practices, soil physical properties, and ecological factors involved (Ncube et al., 2012; Aikins and Afuakwa, 2012). Previous studies have also indicated that variation in fertilizer application rate and time of application has an influence on plant growth and yield (Zerihun and Hailu, 2017); nutrient availability, nutrient uptake and photosynthetic activities (Zhao et al., 2008; Razaq et al., 2017). $\mathrm{T}_{3}$ $\left(\mathrm{N}_{635} \mathrm{P}_{210} \mathrm{~K}_{315} \mathrm{Kg} / \mathrm{ha}\right)$ demonstrated the highest influence on plant height, number of leaves per plant, leaf width and leaf length. However, further increase in fertilizer treatment levels had a negative influence on different growth parameters (Abderrahmane et al., 2018). Results of this study indicate that $T_{3}(635 \mathrm{~kg} / \mathrm{ha}$ urea, $210 \mathrm{~kg} / \mathrm{ha}$ of triple superphosphate and $315 \mathrm{~kg} / \mathrm{ha}$ of potassium chloride) is the optimal fertilizer treatment application rate that could potentially produce the best yield of burdock leaves for vegetable production in the Western Cape Province of South Africa under similar environmental conditions. However, Qasim (2018) reported the best yield of burdock at $\mathrm{N}_{100} \mathrm{~K}_{100} \mathrm{~kg} / \mathrm{ha}$ with a uniform application of phosphorous in the field. Also, Wu et al. (2016) reported the best treatment combination of $30 \%$ vermicompost combined with nitroxin on growth parameters of burdock. It has been proven that optimum nitrogen supply is critical for growth and development in plants and its availability and concentration in plant tissues affect the partitioning of plant biomass (Bown et al., 2010). This may be due to its role in the formation of amino acid, which is the base for the building of Indole acetic acid (IAA) auxin, which stimulated cell division and elongation, and growth of epical meristem. Phosphorous, also being a primary nutrient for plant growth, its optimal amount is critical for optimum production and quality (Zapata and Zaharah, 2002). This may have also led to the increase in shoot biomass, influencing the number of leaves, leaf length and leaf width of burdock in this experiment across the different treatments with the highest influence showcased by $\mathrm{T}_{3}$. Moreover, nitrogen and phosphorous are very critical to dry matter partitioning on shoot tip where metabolism is high with rapid cell division and the number of leaves which is a function of plant height (Ndakidemi and Dakora, 2007). The differences in growth parameters in this study may have been a direct result of the differences in the rates of fertilizer application. Generally, this study indicated that $T_{3}$ is the optimum level of fertilizer combination for the cultivation of burdock in this soil type in Cape Winelands of the Western Cape Province of South Africa. $T_{4}$ had the greatest effect on leaf width and chlorophyll content. This can be attributed to the fact that nitrogen is the most important element in chlorophyll biosynthesis (Razaq et al., 2017) which influences leaf width. Hence, nitrogen promotes the formation of active photosynthetic pigments by increasing the amount and thylakoid proteins in leaves. Also, green pigments in leaves depend on phosphorous concentration since the 
biosynthesis of pigment molecules depends on the uptake of optimal phosphorous levels demonstrated by $\mathrm{T}_{4}$ in this study. The different time of data collection had a significant influence on all the morphological characteristics investigated. This indicates that growth parameters in burdock are greatly influenced by nutrient availability, time of data collection and plant age. The fifth time of data collection demonstrated the highest effect in all the parameters recorded. However, there was no significant difference in leaf length and leaf width at the fourth and fifth time of data collection, indicating the potential stage of maturity of this species. Fertilizer treatments recorded significant effects on yield-related parameters of burdock (Arctium lappa L.) in this study. $\mathrm{T}_{3}$ recorded the highest total fresh weight and fresh root weight, indicating the best treatment combination for this study. This may be attributed to the fact that lower phosphorous availability in soil is known to stimulate larger roots in some plant species (Williamson et al., 2001) and root length, since long fine roots are more efficient in nutrient acquisition than short fine roots (Ma et al., 2001) which may have resulted to an increase in total root biomass demonstrated by $\mathrm{T}_{3}$. However, $\mathrm{T}_{4}$ and $\mathrm{T}_{5}$ had no significant difference with $\mathrm{T}_{3}$. Furthermore, $\mathrm{T}_{3}$ recorded the highest dry root weight and total dry weight (TDW) since total dry weight (TDW) is a function of total fresh weight (TFW). $T_{5}$ recorded the highest fresh leaf and dry leaf yield. This indicates that $T_{5}$ combination is a potential treatment for vegetable production of burdock leaves while $\mathrm{T}_{3}$ can be used for the cultivation of burdock roots as indicated by this study.

\section{Conclusion}

The cultivation of Burdock (Arctium lappa L.) was highly influenced by fertilizer treatments. The results of the study demonstrated that burdock can successfully grow in the Winelands District of the Western Cape Province of South Africa. The application of $\mathrm{N}_{846} \mathrm{P}_{280} \mathrm{~K}_{315} \mathrm{Kg} / \mathrm{ha}$ of fertilizer combination could be recommended for potential folia vegetable cultivation. This can be a possible solution to meet up with the demand for daily consumption of burdock leaves as a very nutritive vegetable as stimulant of appetite and as a good remedy for indigestion problems. Also the young tender shoots harvested before flowering are used in salads. While the fertilizer combination $\left(\mathrm{N}_{635} \mathrm{P}_{210} \mathrm{~K}_{315} \mathrm{~kg} / \mathrm{ha}\right)$ could be recommended for burdock root cultivation. a possible solution to meet up with the demand of burdock roots as a source of food salad and root herbs. The roots are rich in phytochemicals with anti-oxidant property, diseases prevention and health promoting properties. This may contribute to the economic growth of South Africa via the provision of medicinal plant materials to pharmaceutical industries and herbal practitioners with the possibilities of job creation on the awareness of medicinal plant cultivation by communities as an alternative sector in agriculture. The cultivation of this species can also provide a potential market for vegetable production; a possible solution to food security and job creation to communities. However, further investigation needs to be tested in the field as well as optimization studies on secondary metabolites of interest for quality assurance and consistent availability of plant materials. This will provide a good platform for price negotiation for a better buying price of plant materials by our pharmaceutical industries and herbal practitioners.

\section{Acknowledgement}

This article is a part of the research findings of a project supported by the National Research Foundation (DST/TIA) under grant No.108580, an innovative research project to cultivate some potential medicinal plants that are not found in South Africa but are in high demand locally. Also, the assistance of Dr. Bisi Oladele in Australia for her relentless effort in seeds sourcing from the company "The Seed Collection" in Australia for this research.

Disclaimer: None.

Conflict of Interest: None.

Source of Funding: This study was supported by the National Research Foundation, South Africa (NRF/DST/TIA) under grant No.108580.

\section{References}

Abderrahmane B, Mohammed I, Ahmed D, Mounira L, Chaouki A, Soukaina C and Abdelmjid Z, 2018. Effect of NPK fertilizer on the growth, yield, quality and mineral nutrition of new sweet plants in Morocco (Stevia rebandiana bertoni). Am. J. Biol. Life Sci. 6(3): 36- 43.

Aikins SHM and Afuakwa JJ, 2012. Effects of four tillage practices on soil properties under cowpea. Agric. Biol. J. N. Am. 3(1): 17-24. 
Bown HE, Watt MS, Clinton PW and Mason EG, 2010. Influence of ammonium and nitrate supply on growth, dry matter partitioning, $\mathrm{N}$ uptake and photosynthetic capacity of Pinus radiata seedlings. Trees. 24(6): 10971107.

Chang HJ, Huang WT, Tsao DA, Huang MK, Lee CS, Lin RS, Yang CS and Yeh SC, 2009. Identification of burdock (Arctium lappa L.) using PCR sequencing. Fooyin J. Health Sci.1: 28-32.

Chan YS, Cheng LN, Wu JH, Chan E, Kwan YW, Lee SM, Leung GP, Yu PH and Chan SW, 2011. A review of pharmacological effects of Arctium lappa $\mathrm{L}$ (burdock). Inflammopharmacol. 5: 245-254. DOI: 10.1007/s10787-010-0062-4.

El-Darier SM and Salama S, 2016. Arctium lappa L (Asteraceae); a new invasive high specific Medicinal plant growing in Egypt. Pyrex J. Plant Agric. Res. 2(2): 4-53.

Hammed TB, Oloruntoba EO and Ana GREE, 2019. Enhancing growth and yield of crops with nutrients enriched organic fertilizer at wet and dry seasons in ensuring climate-smart agriculture. Int. J. Recycl. Organic Waste Agric. 8: 81-92

Ichami SM, Shepherd KD, Sila AM, Stoorvogel JJ, Hoffland E, 2019. Fertilizer response and nitrogen use efficiency in African smallholder maize farms. Nutr. Cycl. Agroecosyst. 113: 1-19.

Ma Z, Bielenberg DG, Brown KM and Lynch JP, 2001. Regulation of root hair density by phosphorus availability in Arabidopsis thaliana. Plant Cell. Environ. 24(4): 459-467.

Maroyi A, 2013. Traditional uses of medicinal plants in south- central Zimbabwe: review and perspectives. J. Ethnobiol. Ethnomed. 9: 31. DOI: 10.1186/1746-42699-31.

Ncube B, Finnie JF and Van-Staden J, 2012. Quality from the field: The impact of environmental factors as quality determinants in medicinal plants. South Afr. J. Bot. 82: 11-12.

Ndakidemi PA and Dakora FD, 2007. Yield components of nodulated cowpea (Vigna unguiculata (L.) Walp) and maize (Zea mays) plants grown with exogenous phosphorus in different cropping systems. Aust. J. Exp. Agric. 47: 583-589.

Qasim ASZ, 2018. Effect of Nitrogen fertilization and harvesting date on growth of Burdock Plant (Arctium lappa $\mathrm{L}$.) and total phenols content in leaves. Biochem. Cell. Arch. 18(2): 2131-2134.

Razaq M, Zhang P, Shen HI and Salahuddin, 2017. Influence of nitrogen and phosphorus on growth and root morphology of Acer mono. PLoS ONE. 12(2): e0171321. https://doi.org/10.1371/journal.pone.0171321.
Tanga M, Lewu FB, Oyedeji OA and Oyedeji OO, 2018. Cultivation of medicinal plants in South Africa: a solution to quality assurance and consistent availability of medicinal plant materials for commercialization. Acad. J. Med. Plant. 6(7): 168-177.

Tousch D, Bidel LPR and Cazals G, 2014. Chemical analysis and antihhyperglycemic activity of an original extract from burdock root (Arctium Lappa L). J. Agric. Food Chem. 62(31): 7738-774.

Wang $\mathrm{H}$ and $\mathrm{Wu} \mathrm{W}, 2013$. Studies on the physiological functions of burdock inulin. Med. Plant. 4(11/12): 5860.

Williamson L, Ribrioux S, Fitter A and Leyser O, 2001. Phosphate availability regulates root system architecture in Arabidopsis. Plant Physiol. 126(2): 875882.

Wu J, Radnezhad H, Loni A, Hassanvand A, Abari MF and Zaremanesh H, 2016. Effects of Biofertilizers on the Morphological Characteristics of the burdock. Appl. Ecol. Environ. Res. 15(4): 1715-1731.

Zapata F and Zaharah AR, 2002. Phosphate availability from phosphate rock and sewage sludge as influenced by addition of water soluble phosphate fertilizers. Nutrient Cycl. Agroecosystem. 1(63): 43-48.

Zerihun A, and Hailu F, 2017. Effects of nitrogen rates and time of application on yield of maize: rainfall variability influenced time of nitrogen application. Int. J. Agron. 2017. 1545280.

Zhao D, Kane M, Borders B and Harrison M, 2008. Pine growth response to different sites- preparations methods with or without post plant herbaceous weed control on North Florida`s Lower Coastal Plain. Forest Ecol. Manage. 255(7): 2512-2523.

Xu DP, Li Y, Meng X, Zhou T, Zhou Y, Zheng J, Zhang JJ and Li HB, 2017. Natural antioxidant in food and medicinal plants: Extraction, assessment and resources. Int. J. Mol. Sci. 18(1): 96. DOI: 10.3390/ijms18010096.

\section{Contribution of Authors}

Tanga M: Designed and conducted the study, literature review and article write up Lewu FB: Helped in study design, supervised the study and final approval of article

Oyedeji AO: Helped in study design, supervised the study and write up of article Oyedeji OO: Helped in study design, supervised the study and write up of article 